\title{
The Effects of the Horticulture-Mathematics Integration Program on Mathematical Attitude and Money Calculating Ability of Students with Intellectual Disabilities
}

\author{
Suk Young Yun ${ }^{1}$, Yu Jung Nam²*, Yong II Kwon², and Byung Jin Choi ${ }^{1}$ \\ ${ }^{1}$ Professor, Department of Horticulture, Daegu Catholic University, Gyeongsan 38430, Korea \\ ${ }^{2}$ Doctoral student, Department of Horticulture, Daegu Catholic University, Gyeongsan 38430, Korea
}

\section{ABSTRACT}

Background and objective: The concept of 'money' in the numbers and operations domain is a fundamentally necessary domain of economic life. This study was conducted to examine the effects of a horticulture-mathematics integration program on mathematical attitude and money calculating ability of high school students with intellectual disabilities.

Methods: We analyzed the changes in the mathematical attitude and money calculating ability of students with mild intellectual disabilities in S special school in the city of D, Republic of Korea, with 12 students in the control group and 12 students in the experimental group, from August 27 to October 29, 2019.

Results: The results of the comparison showed no statistically significant changes in the three items of mathematical attitude for the control group, while the experimental group, which took part in the horticulture-mathematics integration program, showed statistically significant differences across all three items, such as self-concept about the subject $(p=.003)$, attitude toward the subject $(p=.004)$, and study habit related to the subject $(p=.012)$. The horticulture-mathematics integration program, which was developed by integrating horticultural activities and the mathematics curriculum, used plants and horticultural activities to provide students with positive experiences in mathematics. These included the sense of closeness, curiosity, interest, attention, and enjoyment, leading to positive changes in mathematical attitude. In terms of money calculating ability, both the control group and experimental group showed statistical differences across the three items, but the experimental group showed greater degrees of increase, 15.0 or more, in the scores compared to the control group.

Conclusion: These results suggest that utilizing horticultural materials as a part of purchase learning programs with elements of money calculation chapters in the mathematics curriculum could lead to the improvement of students' ability in money calculation. These positive changes are thought to be related to the high degrees of interest in horticulture among students, which led to active participation in the program and enabled the simple and repeated purchase activities in the program to generate positive changes in the money calculation ability of the students.

Keywords: horticultural activities, mathematics curriculum, purchase activities program, special school

\section{Introduction}

The purpose of education for students with intellectual disabilities is to teach them how to live an independent life as an individual in the community as well as a member of the society coexisting with others (Choi and Lee, 2000;
Lee and Kang, 2014). Intellectual disabilities last for a lifetime, but proper education during growth affects independent life in adulthood (Szymanski and King, 1999). Special education in South Korea today is focused on cultivating core competencies necessary for community life and social integration with the 2015 Revised Curriculum (Woo

\footnotetext{
This paper was funded by the research funds of Daegu Catholic University in 2019.

Received: April 9, 2020, Revised: May 25, 2020, Accepted: June 4, 2020

First author: Suk Yung Yun, yune1004@cu.ac.kr, (D) https://orcid.org/0000-0002-5862-0021

*Corresponding author: Yu Jung Nam, hosa74@hanmail.net, (10) https://orcid.org/0000-0002-0798-2639
} 
et al., 2015). Mathematics in the basic curriculum of special education is the subject to develop the ability and attitude to rationally solve problems faced in real life by mathematically exploring objects and phenomenon in life and obtaining mathematical knowledge and skills (Ministry of Education[MOE], 2015). In particular, the educational objective of high school mathematics is to teach how to use mathematical knowledge in solving real-life problems such as economic and vocational life to prepare for adulthood and cultivate a desirable attitude toward mathematics, thereby helping students cope with those problems positively and actively (Jo and Park, 2016; Kim and Kang, 2015; MOE, 2015). For students with intellectual disabilities, mathematics is a subject that must be learned constantly and repeatedly, thereby playing a key role in learning other subjects and affecting their learning abilities (Sagong, 2017). The basic mathematics curriculum is in five domains such as Numbers and Operations, Measurements, Patterns, Figures, and Probability and Statistics, through which students learn contents related to real life such as perception of numbers, concept of positive numbers, and concept of time (Kim et al., 2012; MOE, 2015). Among them, the concept of 'money' in the Numbers and Operations domain is a fundamentally necessary domain of economic life that must be studied with importance for independent life. Making purchases using money is a teaching method that requires repeated, step-by-step guidance for students with intellectual disabilities considering their characteristics and levels (Cho and Choi, 2011; Lee and Kang, 2014).

Despite the importance of mathematics, most students with intellectual disabilities have low concentration and insufficient intellectual abilities, thereby showing low interest in mathematics as they perceive it as a difficult subject that has clear sequences and abstract concepts and requires high concentration and accuracy (Haylock, 1991). Furthermore, the cumulative sense of failure leads to lower learning motives and passive learning properties, thereby resulting in low self-efficacy and mathematical attitude (Kim et al., 2019; Sagong, 2017; Smith et al., 2006). For students with intellectual disabilities to obtain mathematical concepts and knowledge and apply them to real life, it is effective to implement a class using concrete objects to manipulate, which can interest or intrigue them. It is also necessary to adopt a teaching method that integrated the contents of other subjects so that the students can experience everyday scenes by creating various simulation scenarios (Lee, 2013; Lee and kang, 2014; MOE, 2018).

Horticultural education was integrated into other subjects and developed as horticultural programs for children in the US and other countries as a set of natural activities to experience nature up close (Kwack et al., 2009). Horticulture can be used as a key subject to teach in association with other subjects and help students clearly perceive the concepts learned abstractly in the textbooks through horticultural activities (DeMarco et al., 1999; Kim et al., 2014). Horticultural activities can help students learn problem solving skills and mathematics (White et al., 2006), and growing plants in particular raises students' self-esteem, confidence and interest in learning (Kim et al., 2014; Kwack and Kim, 2018). The horticultural integration program for mathematics titled "All in the Garden!" created in 2007 by the National Institute of Horticultural and Herbal Science (NIHHS) by integrating horticulture with mathematics was carried out in mathematics class with contents that can be used indoors in elementary school. As a result, the NIHHS developed a program that stimulates observation and curiosity, helps students understand the number concept by solving real-life problems, and induces positive attitudes towards the mathematics subject (NIHHS, 2008). Previous studies on horticultural therapy for students with intellectual disabilities are as follows. Lee (2012) implemented horticultural therapy for occupational rehabilitation of adolescents with intellectual disabilities and found that there was a significant increase in attention, number concept, decision making and thinking skills among horticultural cognition. Moreover, a program using floral designs improves problem solving skills, cognitive skills and participation as well as social adaptation behaviors such as self-concept, interpersonal skills and self-expression, thereby affecting cultivation of work adjustment skills for students with intellectual disabilities (Yoon et al., 2009). Mathematics is a subject comprised of patterns and principles found in nature, and nature has many mathematical elements that enable all kinds of mathematical activities (Kim and Cho, 2008; Lee, 2009). For students with intellectual disabilities, horticultural activities give sense of 
closeness rather than fear about the tasks as they use natural objects they can easily encounter in real life. Horticultural activities instill curiosity and interest in students with intellectual disabilities that feel difficulty in abstract thinking and have short attention span, increasing their sense of achievement and confidence through real object modeling and self-operation (Choi, 2017; Choi and Lee, 2000). Horticultural activities also include the methods to provide necessary materials in the program depending on the purpose of activities. Developing a program to purchase materials for horticultural activities, creating simulation scenarios and repeating them every session will provide actual learning experience of proactive choice and purchase for students with intellectual disabilities that tend to be passive and dependent in purchasing goods (Lee and Kang, 2014). Therefore, studying, developing and applying a horticulture-mathematics integration program for students with intellectual disabilities will enable them to more easily understand mathematical concepts and perform mathematical tasks. The integration program is a method to obtain high educational effects by breaking down disciplinary boundaries and integrating and reconstructing knowledge and experience of each subject (Park, 2017). Since there are no subjects related to horticulture in the basic curriculum for special needs high schools, there are limitations in organizing an integration program among subjects. However, by helping students with disabilities understand the mathematical concepts using horticultural activities with various proved effects, it will be possible to provide suitable teaching methods in cultivating positive mathematical attitude based on experience of success and sense of achievement (Choi and Lee, 2000: Lee, 2013) as well as money calculating ability that can be applied to real life. Mathematical attitude refers to the level of confidence learners have in mathematics, attention, application of learning skills, interest in mathematical studies, and sense of purpose (Shin et al., 1992). This study is conducted to examine and develop mathematics and teaching methods using horticultural programs to improve mathematical attitude and thinking skills of high school students with intellectual disabilities, apply them to educational settings, and determine specifically whether the program cultivates positive mathematical attitude and money calculating ability.

\section{Research Methods}

\section{Subjects}

We selected 12 subjects in the experimental group and 12 subjects in the control group among students with intellectual disabilities attending S Special School located in D city who have an IQ of 50-70. The experimental group was comprised of five students in the first year, two in the second year and five in the third year (nine male and three female), and the control group was comprised of four students in the first year, one in the second year and seven in the third year (11 male and one female).

\section{Tools}

\section{Experimental design}

This study was conducted to determine change in mathematical attitude and money calculating ability of high school students with intellectual disabilities brought by a horticulture-mathematics integration program that applied a horticultural program to the mathematics subject. The differences between the experimental group and control group were analyzed using the pretest-posttest control group design. The experimental group participated in the horticulture-mathematics integration program in addition to the conventional class, while the control group only participated in the conventional class focused on the curriculum. Both groups were comparatively analyzed by equally testing mathematical attitude (Shin et al., 1992) and money calculating ability (Lee and Kang, 2014) before and after the program.

\section{Program design}

This study was conducted to cultivate mathematical attitude and money calculating ability of high school students with intellectual disabilities by studying and developing a horticulture-mathematics integration program. The contents of high school Mathematics I and II in the basic 2015 Revised Curriculum for special education were analyzed and tested by a special school in-service teacher with 10 years of experience who have a master's degree in special education and mathematics. After that, units and topics that 
can be taught by integrating mathematics and horticulture among 12 units of Mathematics I were selected. The program was formed in 10 sessions with reference to classes 1-3 considering the level of learning activities and applied to the students. To develop money calculating ability, we designed the program with reference to the "Using Currency" unit in Numbers and Operations (MOE, 2018) and divided the levels so that students can purchase the materials before horticultural activities using replica money. Before the program, the same amount of money was given to the students - ten 10-won coins, ten 50-won coins, ten 100-won coins, ten 500-won coins, five 1,000-won bills, two 5,000-won bills, and two 10,000-won bills - and the materials were presented with the price marked on them. Horticultural activities were comprised of planting, floral design and craft activities with reference to the studies on horticultural therapy implemented on students with intellectual disabilities (Lee, 2012), more specifically referring to the National Institute of Horticultural and Herbal Science's 'All in the Garden'(NIHHS, 2008) and the horticulture-mathematics integration program by Lee (2009). For plant selection, we used plants in the textbooks of the basic curriculum for special education in Park (2011) with high frequency of appearance or plants suitable to apply in the season when the program was carried out. Among 52 species of flowering plants, we used the ones familiar to and safe for students, such as Rosa hybrida (32 times), Helianthus annuus L. (23 times), Chrysanthemum morifolium (20 times), Cosmos bipinnatus Cav. (14 times), Dianthus caryophyllus L. (seven times), Hedera helix (four times), and among 19 species of fruit trees, we used Citrus limon (seven times). The details of the 10 sessions of the horticulturemathematics integration program are as follows.

Session 1 is Unit 1, 4-Digit Numbers (1), in which students stuck a bundle of 100 beads on cylindrical vases and arranged flowers to learn and made 1,000, after which they gathered 10 vases to make a flower basket of 1,000 . Session 2 is Unit 2, 3-Digit Addition and Subtraction, in which students placed coffee beans and leaf potpourri in 100 slots and added them to understand addition without regrouping, after which they drew trees on canvas, attached coffee beans on the trunks and leaf potpourri on the crown, and created a fragrant tree collage. Session 3 is Unit 3,
Cuboids and Cubes, in which students were to understand the components of cuboids by separating cuboids made with Cornus sericea 'Flaviramea' and arrange flowers in order to understand the number of edges and faces as well as shapes, after which they put them in bottles and made herbariums. Session 4 is Unit 4, Cuboids and Cubes, in which students were to determine the faces of cubes by equally arranging six flowers of Rosa hybrida (Miniature Roses) each on six cube floral foams in the size of $5 \times 5 \times 5$ $\mathrm{cm}$ and creating a topiary, thereby learning that the faces have the same shape. Session 5 is Unit 5, Patterns and Correspondence (1), in which students were to understand correspondence and patterns by examining the 1:5 correspondence pattern with five leaves divided in one stem of Pachira aquatica to determine 1:1 correspondence of plant and flowerpot. Session 6 is Unit 6, Day Planning, in which students were to determine the daily rules according to time flow by creating a $20 \mathrm{~cm}$-diameter wreath by expressing their daily routines with Gossypium hirsutum, dried lemons, fake applies and pine cones. Session 7 is Unit 7, Basics of Fractions, in which students equally divided the whole cylindrical container into three parts to understand fractions, put two types of colored stones up to $2 / 3$ of the container and planted Tillandsia Ionantha. Session 8 is Unit 8, Basics of Division, in which students divided soap base provided to two students into an equal number of pieces, added color with paprika and sweet pumpkin powder, and made persimmon-shaped soap. Session 9 is Unit 9 , Capacity $(\mathrm{mL})$, in which students made tumblers decorated in pressed flowers to test capacity and find out the relationship between $\mathrm{L}$ and $\mathrm{mL}$, poured $1 \mathrm{~L}$ of water into a $400 \mathrm{~mL}$ tumbler, and learned the relationship of capacity. Session 10 is Unit 10, Line Graph, in which students were to learn the order of drawing a line graph by planting Hedera helix and inducing stems on the structure, after which they learned how to measure the longest and the second-longest stem with a ruler and draw them on the graph. They measured the lengths once a week and recorded their growth to understand the line graph. Moreover, the program to develop money calculating ability is Unit 11, Using Currency (1), (2), in which students in Sessions 1-2 identified the face value of bills and coins and then were to purchase two materials. In Sessions 3-5, Calculating 
the Prices, students were to find money and purchase 3 different materials in the same price, a couple of thousands of won, in Sessions 3-4, and calculate the amount that added the prices of two materials and purchase the materials in the relevant amount. In Sessions 6-7, Calculating the
Change, students calculated the change after buying things within 5,000 won. In Sessions 8-10, Purchasing Items, students were to purchase materials within 10,000 won. The program was designed so that there is no rounding up of the sum when purchasing two or more items (Table 1, Fig. 1).

Table 1. Horticulture mathematics integration program used in this study

\begin{tabular}{|c|c|c|c|c|c|c|}
\hline Session & Area & Unit & Subject & Program & $\begin{array}{c}\text { Horticultural } \\
\text { activity }\end{array}$ & Plants \\
\hline 1 & $\begin{array}{l}\text { Numbers and } \\
\text { calculation }\end{array}$ & $\begin{array}{l}\text { - 4-digit numbers } \\
\text { - Using currency }\end{array}$ & $\begin{array}{l}\text { - Concept of } 1000 \\
\text { - Buying items that } \\
\text { have the same price }\end{array}$ & $\begin{array}{l}\text { - Making a } 1000 \text { flower basket } \\
\text { Knowing the numbers (on the } \\
\text { bill - buying } 2 \text { ingredients with } \\
\text { a paper bill) }\end{array}$ & $\begin{array}{l}\text { Cylindrical } \\
\text { vase flower } \\
\text { arrangement }\end{array}$ & $\begin{array}{l}\text { Helianthus annuus L. } \\
\text { Rosa hybrida } \\
\text { Chrysanthemim morifolium } \\
\text { Dianthus caryophyllus L. }\end{array}$ \\
\hline 2 & $\begin{array}{l}\text { Numbers and } \\
\text { calculation }\end{array}$ & $\begin{array}{l}\text { - 3-digit addition } \\
\text { and subtraction } \\
\text { - Using currency }\end{array}$ & $\begin{array}{l}\text { - Addition (3-digit } \\
\text { with no need for } \\
\text { carrying) } \\
\text { - Buying items that } \\
\text { have the same price }\end{array}$ & $\begin{array}{l}\text { - Adding coffee beans and } \\
\text { fragrant leaves } \\
\text { - Knowing the numbers (on the } \\
\text { coin - buying } 2 \text { ingredients } \\
\text { with coins) }\end{array}$ & $\begin{array}{l}\text { Fragrant tree } \\
\text { collage }\end{array}$ & $\begin{array}{l}\text { Coffee bean } \\
\text { Reindeer moss }\end{array}$ \\
\hline 3 & $\begin{array}{l}\text { Figures/ } \\
\text { Numbers and } \\
\text { calculation }\end{array}$ & $\begin{array}{l}\text { - Rectangular and } \\
\text { square cuboids } \\
\text { - Using currency }\end{array}$ & $\begin{array}{l}\text { - Rectangular cuboid } \\
\text { (number of edges } \\
\text { and vertices) } \\
\text { - Buying items that } \\
\text { have the same price }\end{array}$ & $\begin{array}{l}\text { - What does the box contain? } \\
\text { prices, finding currencies that } \\
\text { are required to pay for } 2 \\
\text { different types of ingredients } \\
\text { and purchasing) }\end{array}$ & $\begin{array}{l}\text { Making a } \\
\text { herbarium }\end{array}$ & $\begin{array}{l}\text { Hydrangea macrophylla } \\
\text { Rumohra adiantiformis } \\
\text { Bellis perennis L. } \\
\text { (preserved flower) } \\
\text { Cornus sericea 'Flaviramea' }\end{array}$ \\
\hline 4 & $\begin{array}{l}\text { Figures/ } \\
\text { Numbers and } \\
\text { calculation }\end{array}$ & $\begin{array}{l}\text { - Rectangular and } \\
\text { square cuboids } \\
\text { - Using currency }\end{array}$ & $\begin{array}{l}\text { - Square cuboid } \\
\text { (six faces with same } \\
\text { shape) } \\
\text { - Buying items that } \\
\text { have the same price }\end{array}$ & $\begin{array}{l}\text { - It's the same shape. } \\
\text { - Calculating the price (4-digit } \\
\text { prices, finding currencies that } \\
\text { are required to pay for } 3 \\
\text { different types of ingredients } \\
\text { and purchasing) }\end{array}$ & $\begin{array}{l}\text { Making } \\
\text { topiary }\end{array}$ & $\begin{array}{l}\text { Rosa hybrida } \\
\text { (Miniature Roses) } \\
\text { Reindeer moss }\end{array}$ \\
\hline 5 & $\begin{array}{l}\text { Regularity/ } \\
\text { Numbers and } \\
\text { calculation }\end{array}$ & $\begin{array}{l}\text { - Regularity and } \\
\text { correspondences } \\
\text { - Using currency }\end{array}$ & $\begin{array}{l}\text { - Learning regularity } \\
\text { and correspondences } \\
\text { (relations and } \\
\text { regularity) } \\
\text { - Buying items that } \\
\text { have the same price }\end{array}$ & $\begin{array}{l}\text { - Five fingers in one stem } \\
\text { - Calculating the price (prices } \\
\text { with both } 4 \text { th and 3rd digits, } \\
\text { finding currencies that are } \\
\text { required to add up to the price } \\
\text { and purchasing) }\end{array}$ & $\begin{array}{c}\text { Planting } \\
\text { foliage plants }\end{array}$ & Pachira aquatica \\
\hline 6 & $\begin{array}{l}\text { Measurement/ } \\
\text { Numbers and } \\
\text { calculation }\end{array}$ & $\begin{array}{l}\text { - Day planning } \\
\text { - Using currency }\end{array}$ & $\begin{array}{l}\text { - My day plan (daily } \\
\text { regularity) } \\
\text { - Buying items that } \\
\text { have the same price }\end{array}$ & $\begin{array}{l}\text { - What does my day look like? } \\
\text { - Calculating the change (buying } \\
\text { items within the KRW 5,000 } \\
\text { level and calculating the change) }\end{array}$ & $\begin{array}{l}\text { Making a } \\
\text { wreath }\end{array}$ & $\begin{array}{l}\text { Gossypium hirsutum } \\
\text { Citrus limon(dried) } \\
\text { Conifer cone, Strobile }\end{array}$ \\
\hline 7 & $\begin{array}{l}\text { Numbers and } \\
\text { calculation }\end{array}$ & $\begin{array}{l}\text { - Basics of fractions } \\
\text { - Using currency }\end{array}$ & $\begin{array}{l}\text { - Total and part } \\
\text { - Buying items that } \\
\text { have the same price }\end{array}$ & $\begin{array}{l}\text { - One can still be divided } \\
\text { - Calculating the change (buying } \\
\text { items within the KRW 5,000 } \\
\text { level and calculating the change) }\end{array}$ & Transplanting & Tillandsia Ionantha \\
\hline 8 & $\begin{array}{c}\text { Numbers and } \\
\text { calculation }\end{array}$ & $\begin{array}{l}\text { - Basics of division } \\
\text { - Using currency }\end{array}$ & $\begin{array}{l}\text { - Dividing equally } \\
\text { - Buying items that } \\
\text { have the same price }\end{array}$ & $\begin{array}{l}\text { - Divide equally between the two } \\
\text { - Buying (buying items within } \\
\text { the KRW 10,000 level) }\end{array}$ & $\begin{array}{l}\text { Making hand } \\
\text { formed soap }\end{array}$ & $\begin{array}{l}\text { Capsicum annuum var. } \\
\text { angulosum(Paprika powder) } \\
\text { Cucurbita maxima } \\
\text { (Kabocha powder) }\end{array}$ \\
\hline 9 & $\begin{array}{l}\text { Measurement/ } \\
\text { Numbers and } \\
\text { calculation }\end{array}$ & $\begin{array}{l}\text { - Capacity (mL) } \\
\text { - Using currency }\end{array}$ & $\begin{array}{l}\text { - Learning capacity } \\
\text { - Buying items that } \\
\text { have the same price }\end{array}$ & $\begin{array}{l}\text { - My very own special water } \\
\text { bottle } \\
\text { - Buying (buying items within } \\
\text { the KRW 10,000 level) }\end{array}$ & $\begin{array}{l}\text { Decorating } \\
\text { tumblers with } \\
\text { pressed } \\
\text { flowers }\end{array}$ & $\begin{array}{l}\text { Chrysanthemim frutescens } \\
\text { Cosmos bipinnatus Cav. } \\
\text { Hydrangea macrophylla } \\
\text { (pressed flower) }\end{array}$ \\
\hline 10 & $\begin{array}{l}\text { Data and } \\
\text { possibility/ } \\
\text { Numbers and } \\
\text { calculation }\end{array}$ & $\begin{array}{l}\text { - Line graph } \\
\text { - Using currency }\end{array}$ & $\begin{array}{l}\text { - Line graph } \\
\text { - Buying items that } \\
\text { have the same price }\end{array}$ & $\begin{array}{l}\text { - How much did it grow? (plant } \\
\text { growth graph) } \\
\text { - Buying (buying items within } \\
\text { the KRW 10,000 level) }\end{array}$ & $\begin{array}{c}\text { Training } \\
\text { plants }\end{array}$ & Hedera helix \\
\hline
\end{tabular}




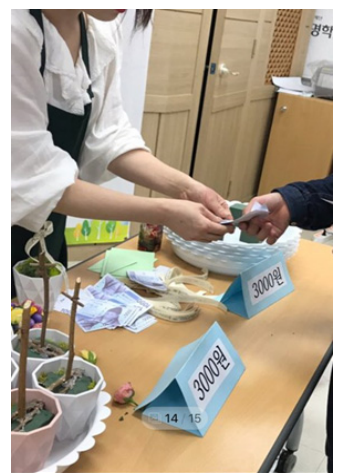

(A)

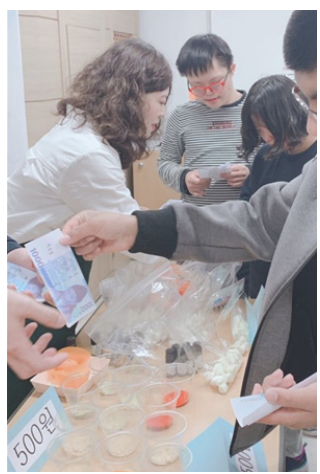

(B)

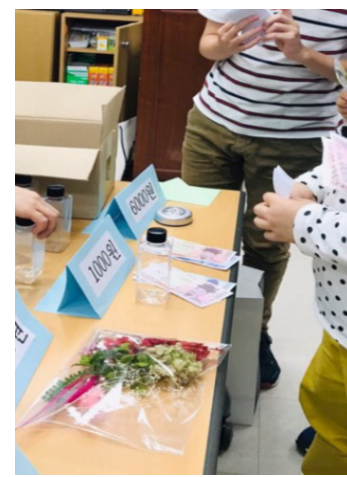

(C)

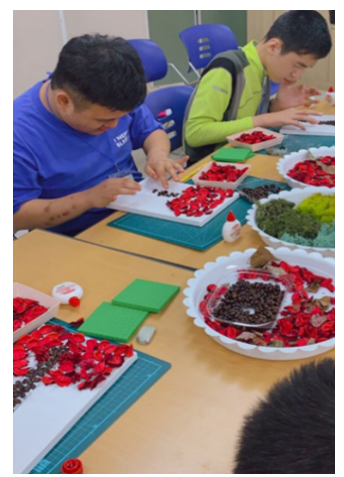

(D)

Fig. 1. Purchasing materials for horticultural activities $(A-C)$ and participating in horticultural activity (D) in horticulture-mathematics integration program.

\section{Program implementation}

This study was conducted in total 10 sessions, 60 minutes per session once a week from 6 to 7 p.m. every Tuesday in the crafts room of the school from August 27 to October 29, 2019. The crafts room was in the size of $30 \mathrm{~m}^{2}$ where there were two $180 \times 140 \mathrm{~cm}$ tables with six students sitting in each. The program was carried out by one main therapist with a Horticultural Therapist RegisteredGrade II certificate (certified by Korean Horticultural Therapy Association) and assistant therapists-one special education teacher with 10 years of experience and one floral designer with a Craftsman Floral Design certificate. The experimental group with 12 students participated in the 10-session program once a week for 60 minutes each during spare time in the evening living in the dorms after school. The horticulture-mathematics integration program was comprised of 10 minutes of introduction, 40 minutes of development, and 10 minutes of wrap-up. There was some relationship building time to motivate the students in the introduction stage, and learning objectives were provided to promote understanding. Photographs related to class were presented on PowerPoint to arouse their interest, and the works they will be making were introduced in real objects. In the development stage, students were to purchase horticultural materials as the first activity for exploration of problems and experiences, and to carry out the horticulture-mathematics integration program as the second activity. The students asking for help were given the least bit of help to promote sense of achievement in completing their works in the development stage, helping them complete them in time. In the wrap-up stage, the students introduced their works, shared their thoughts, and briefly talked about mathematical contents to check their learning objectives. Works to make in the following sessions were introduced in real objects to arouse their interest in the next class.

\section{Assessment tools and analysis method}

\section{Assessment tools}

Persons with intellectual disabilities have a short attention span and are likely to show more concentration when the pretest is conducted on a day without class rather than on the day of the program, and thus the pretest was conducted 3 days before Session 1 of the program began. The posttest was also conducted 3 days after Session 10 of the program was completed, measuring mathematical attitude (Shin et al., 1992) and money calculating ability (Lee and Kang, 2014).

\section{(1) Mathematical attitude test}

The mathematical attitude test is developed to test the learning attitudes toward mathematics in the 'Mathematical Education Evaluation System Research in Pursuit of the True Purpose of Education (III): Developing Evaluation Tools for Mathematics' developed by Shin et al. (1992) in Korean Educational Development Institute. It was cited from the study by Sagong (2017), using the same test used to students with intellectual disabilities. The mathematical 
Table 2. Preliminary homogeneity test of mathematical attitude and money calculation ability between groups

\begin{tabular}{|c|c|c|c|c|c|}
\hline & Item & Control & Experimental & $\mathrm{z}$ & $p$ \\
\hline \multirow{3}{*}{$\begin{array}{l}\text { Mathematical } \\
\text { attitude }\end{array}$} & Self-concept about the subject & 17.0 & 19.3 & -1.099 & $.272^{\mathrm{NS}}$ \\
\hline & Attitude toward the subject & 30.6 & 30.4 & -0.203 & $.839^{\mathrm{NS}}$ \\
\hline & Study habit related to the subject & 28.3 & 28.4 & -0.145 & $.885^{\mathrm{NS}}$ \\
\hline \multirow{3}{*}{$\begin{array}{c}\text { Money } \\
\text { calculation ability }\end{array}$} & Knowing the amount of money & 65.0 & 49.2 & -0.992 & $.321^{\mathrm{NS}}$ \\
\hline & Calculating the price of goods & 52.5 & 48.3 & -0.146 & $.884^{\mathrm{NS}}$ \\
\hline & Calculating change & 41.7 & 39.2 & -0.291 & $.771^{\mathrm{NS}}$ \\
\hline
\end{tabular}

${ }^{\mathrm{NS}}$ Non-significant by Mann-Whitney U test.

attitude is classified into three items: 'self-concept about the subject', 'attitude toward the subject', and 'study habit related to the subject'. 'Self-concept about the subject' measures how learners perceive and evaluate their studies and whether the positive or negative self is formed in studies, and its sub-factors are superiority-inferiority and confidence-loss of confidence. 'Attitude toward the subject' measures whether learners have high interest and sense of purpose toward studies as well as strong learning motives, and its sub-factors are interest-loss of interest, sense of purpose-loss of sense of purpose, and achievement motive-loss of achievement motive. 'Study habit related to the subject' measures the behavior patterns of studying, and its sub-factors are attention, unsupervised learning (active learning), and application of learning skills (efficient learning). This test is in total 40 items: 32 positive and eight negative. The highest score for each item is 3 points, adding up to total 120 points. The test is rated on a 3-point scale: 'Agree' (3 points), 'Neutral' (2 points) and 'Disagree' (1 point) for positive items, and the opposite for negative items. In this test, higher scores indicate more positive mathematical attitude. Cronbach's $\alpha$ of the test was .94 , showing high reliability.

\section{(2) Money calculating ability test}

The money calculating ability test was adopted from 'Effect of functional activity-based mathematics teaching program on money calculating ability of students with intellectual disabilities' by Lee and Kang (2014), reconstructing the test by changing the photos of objects into the ones related to horticulture. The test was in four items such as knowing the amount of money, calculating the price of goods, breaking bills, and calculating change. However, only three items such as knowing the amount of money, calculating the price of goods, and calculating change were used in the test considering the intellectual level of students. The test was in 10 items, each given 10 points and adding up to total 100 points.

\section{Analysis method}

The statistical analysis in this study was conducted using SPSS Program (version 19.0, IBM). The test of homogeneity of the experimental group and control group was analyzed with the Mann-Whitney $U$ test in non-parametric testing. Changes in the pretest and posttest were analyzed with Wilcoxon signed rank test, and the significance level was set at $p<.05$.

\section{Results and Discussion}

\section{Preliminary test of homogeneity between groups}

Table 2 shows the result of analyzing the homogeneity of the control group and experimental group using the Mann-Whitney $U$ test before the horticulture-mathematics integration program. Mathematical attitude assessed in this study did not show a significant difference between the two groups in all items such as self-concept about the subject $(p=.272)$, attitude toward the subject $(p=.839)$, and study habit related to the subject $(p=.885)$. Money calculating ability also did not show a significant difference in all items such as knowing the amount of money $(p=.321)$, calculating the price of goods $(p=.884)$, and calculating change $(p=.771)$, indicating that the two groups were homogeneous and thus this study could be conducted. 
Table 3. Changes in mathematical attitude before and after horticulture-mathematics integration program

\begin{tabular}{|c|c|c|c|c|}
\hline \multirow{2}{*}{ Group } & \multirow{2}{*}{ Item } & Before & After & \multirow{2}{*}{$p$} \\
\hline & & $\mathrm{M}(\mathrm{SD})$ & $\mathrm{M}(\mathrm{SD})$ & \\
\hline \multirow{3}{*}{$\begin{array}{l}\text { Control } \\
(n=12)\end{array}$} & Self-concept about the subject & $17.0(6.7)$ & $17.3(6.2)$ & $.340^{\mathrm{NS}}$ \\
\hline & Attitude toward the subject & $30.6(8.1)$ & $31.1(7.3)$ & $.236^{\mathrm{NS}}$ \\
\hline & Study habit related to the subject & $28.3(5.6)$ & $28.3(5.3)$ & $1.000^{\mathrm{NS}}$ \\
\hline \multirow{3}{*}{$\begin{array}{l}\text { Experimental } \\
\qquad(\mathrm{n}=12)\end{array}$} & Self-concept about the subject & $19.3(5.3)$ & $23.5(3.9)$ & $.003^{* *}$ \\
\hline & Attitude toward the subject & $30.4(6.4)$ & $36.3(5.6)$ & $.004 * *$ \\
\hline & Study habit related to the subject & $28.4(5.3)$ & $31.5(4.3)$ & $.012 *$ \\
\hline
\end{tabular}

Note. Unit: score.

${ }^{\mathrm{NS}}$ Non significant, ${ }^{*} p<.05,{ }^{* *} p<.01$ by Wilcoxon signed-rank test.

\section{Pretest and posttest within group}

\section{Change in mathematical attitude}

As a result of comparing the pretest and posttest scores of change in mathematical attitude of the experimental group that participated in the horticulture-mathematics integration program compared to the control group using the Wilcoxon signed rank test with three items, it was found that the control group did not show a significant difference in all of self-concept about the subject $(p=.340$ ), attitude toward the subject ( $p=.236$ ), and study habit related to the subject $(p=1.000)$. The experimental group showed a statistically significant difference in all of self-concept about the subject $(p=.003)$, attitude toward the subject $(p=.004)$, and study habit related to the subject $(p=.012$; Table 3). In other words, applying the horticulture-mathematics integration program had a positive effect on mathematical attitude of students. This result is similar to the study that implemented the horticulture-mathematics integration program for 12 sessions in math class of Grade 4 students in elementary school and found out that the program helped students find interest in mathematics, thereby increasing the fun of studying mathematics (Kim et al., 2014). This is also supported by the study that mathematical activities through nature form positive attitudes toward mathematics by arousing curiosity and sense of closeness for preschool children (Charlesworth, 2005). This study gave a sense of closeness to students using plants as the main ingredient, and various horticultural activities were used as the learning materials with mathematical contents. However, concrete objects such as horticultural materials and relatively simple activities brought curiosity, pleasure and patience rather than fear of tasks for students with intellectual disabilities that have difficulty in abstract thinking, thereby showing enthusiastic participation (Choi and Lee, 2000). Furthermore, the outcomes also gave them a sense of achievement and confidence, showing that positive mathematical experience with increasing positive emotions may have also affected mathematical attitude (Joo et al. 2012; Sagong, 2017).

\section{Pretest-posttest change in money calculating ability}

As a result of comparing the pretest and posttest scores of change in money calculating ability of the experimental group that participated in the horticulture-mathematics integration program compared to the control group using the Wilcoxon signed rank test with three items, it was found that knowing the amount of money showed a significant difference in both the control group $(p=.046)$ and experimental group $(p=.020)$. Calculating the price of goods also showed a significant difference in the control group $(p=.023)$ and experimental group $(p=.018)$, and calculating change in the control group $(p=.008)$ and experimental group ( $p=.007$; Table 4). Even though the experimental group showed a statistically significant change, the control group also showed a statistically significant change and thus could not prove the effect on improvement of money calculating ability. However, the pretest-posttest difference in mean scores of each item showed that knowing the amount of money increased by 3.3 points in the control group and 24.1 points in the experimental group; calculating the price of goods increased by 6.7 points in the control 
Table 4. Changes in the money calculating ability before and after horticultural-mathematics integration program

\begin{tabular}{|c|c|c|c|c|}
\hline \multirow{2}{*}{ Group } & \multirow{2}{*}{ Item } & Before & After & \multirow{2}{*}{$p$} \\
\hline & & $\mathrm{M}(\mathrm{SD})$ & $\mathrm{M}(\mathrm{SD})$ & \\
\hline \multirow{3}{*}{$\begin{array}{l}\text { Control } \\
(n=12)\end{array}$} & Knowing the amount of money & $65.0(30.6)$ & $68.3(30.7)$ & $.046^{*}$ \\
\hline & Calculating the price of goods & $52.5(27.7)$ & $59.2(30.9)$ & $.023 *$ \\
\hline & Calculating change & $41.7(30.1)$ & $47.5(32.8)$ & $.008^{* *}$ \\
\hline \multirow{3}{*}{$\begin{array}{l}\text { Experimental } \\
\qquad(\mathrm{n}=12)\end{array}$} & Knowing the amount of money & $49.2(38.2)$ & $73.3(27.3)$ & $.020^{*}$ \\
\hline & Calculating the price of goods & $48.3(36.1)$ & $63.3(32.8)$ & $.018^{*}$ \\
\hline & Calculating change & $39.2(34.5)$ & $57.5(40.0)$ & $.007 * *$ \\
\hline
\end{tabular}

Note. Unit: score.

${ }^{*} p<.05,{ }^{*} p<.01$ by Wilcoxon signed-rank test.

group and 15.0 points in the experimental group; and calculating change increased by 5.8 points in the control group and 18.3 points in the experimental group. The experimental group showed an increase of at least 15.0 points in all items, proving that the program had a positive effect on increasing money calculating ability compared to the control group. This is because the program was short with just 10 sessions and had little chance to repeat, and there was not enough time to carry out two activities in the 60-minute session, but students participated enthusiastically in purchasing materials with high interest in horticultural activities. In addition, repeating the activity to find money according to the amount and make payment for purchase resulted in great improvement in all items. This is similar to the result by Lee and Kang (2014) proving in a simulation that purchasing objects on flyers using replica money was effective in improving money calculating ability. Even though it was a simulation, this program has significance in providing guidance for participants to experience mathematical problem solving in the real-life scene of purchasing horticultural materials (Moon and Jeon, 2020).

\section{Conclusion}

This study examined the effects of mathematics and teaching methods using the horticulture-mathematics integration program on mathematical attitude and money calculating ability of high school students with intellectual disabilities. As a result of analyzing pretest-posttest changes in mathematical attitude and money calculating ability be- tween the control group and experimental group, the control group did not show a statistically significant difference in three items of mathematical attitude, whereas the experimental group that participated in the horticulture-mathematics integration program showed a statistically significant difference in all three items such as self-concept about the subject $(p=.003)$, attitude toward the subject $(p=.004)$, and study habit related to the subject $(p=.012)$. Abstractness among the characteristics of mathematics is also referred to as the power to think and can be obtained from specific experience. Therefore, the basic mathematics curriculum must help students learn abstractness through the activities of sufficiently manipulating various concrete materials (Lee, 2013; MOE, 2018). Moreover, enabling students to experience the mathematical concepts in five senses and share emotional communion helps them more easily and conveniently accept mathematics (Lee, 2013). Horticultural activities require direct manipulation using concrete objects mediated by plants, stimulating five senses and enabling the plant as a living organism to share emotional communion with the subject. Accordingly, these activities are necessary for students with intellectual disabilities to understand mathematics. High school also requires students to learn the basic concepts of mathematics and develop desirable learning attitudes toward mathematics with communication activities by mathematically exploring and manipulating objects in everyday life (MOE, 2018). Accordingly, this program is suitable for developing an understanding of mathematical concepts and cultivating positive mathematical attitude by integrating mathematics with plant and horticultural activities that are familiar to 
students with intellectual disabilities. Plants and horticultural activities increased curiosity, interest and attention with splendid colors and diverse forms of plants as well as enthusiastic participation within fear of tasks, thereby showing longer attention span as the sessions went on (Choi and Lee, 2000). Experiencing and manipulating concrete objects like plants and horticultural materials provided multisensory stimulations and affected conceptualization (Choi and Lee, 2000), memory and understanding of mathematical concepts, which increased students answering more enthusiastically and accurately to questions about the concepts learned before the wrap-up stage and the next session. The natural experience of positive mathematical learning such as curiosity, interest, attention and joy in class brought positive changes to mathematical attitude. Moreover, money calculating ability showed a significant difference in all three items for both the control group and experimental group, thereby failing to prove the effect on the increase of money calculating ability. However, according to Moon and Jeon (2020), the internet and home-study materials are used in mathematics classes for students with intellectual disabilities. But since students tend to show difficulty in generalizing the learning contents (Shin, 2017), it is necessary to develop a program to provide real-life scenes at school that can be experienced in the community and guidance to actively solve mathematical problems when required. Therefore, purchasing horticultural materials in the horticulture-mathematics integration program is a highly appropriate attempt at education as students with intellectual disabilities can learn and use money based on active experience of actually purchasing items necessary for the program using real-life materials (Lee and Paik, 2004; Moon and Jeon, 2020).

This study is significant and differentiated from other studies in that it developed a program integrating the basic high school mathematics curriculum for special education with horticultural activities and applied it to high students with intellectual disabilities to verify the change in their mathematical attitude. However, it failed to objectively verify the horticultural program. Thus, further research must verify the program and test generalization of long-term maintenance of the positive mathematical attitude and whether participants solve daily life problems using mathe- matical knowledge and methods. Furthermore, the degree of intellectual disabilities as well as type of disabilities varies among students in special needs schools, and thus there may be limitations in applying the program in mathematics class. Therefore, follow-up research must apply the program to a variety of subjects for a long time. By studying and developing this integrated program to be applied to mathematics class, it would be possible to develop positive attitudes toward mathematics and mathematical thinking skills of students, thereby efficiently solving mathematical problems in independent everyday life.

\section{References}

Charlesworth, R. 2005. Prekindergarten mathematics: Connecting with national standards. Early Child. Educ. J. 32:229-236. https://doi.org/10.1007/s10643-004-1423-7

Cho, B.W. and Y.H. Choi. 2011. The effects of self-instruction strategy on the purchase behaviors of elementary students with intellectual disabilities. Spec. Educ. Res.[Ewha Womans University] 10(1):23-45.

Choi, J.O. and D.W. Lee. 2000. The model of horticultural therapy for improving withdrawal behavior: Connected with severe mentally retarded students. J. Spec. Child. Educ. 1(2):1-31.

Choi, S.J. 2017. A case study on the horticultural program of children with intellectual disabilities in elementary school special class. Master's thesis, Yongin University, Yongin, Korea.

DeMarco, L.W., D. Relf, and A. McDaniel. 1999. Integrating gardening into the elementary school curriculum. HortTechnology 9(2):276-281. https://doi.org/10.21273 /HORTTECH.9.2.276

Haylock, D. 1991. Teaching mathematics to low attainers, 8-12. New York, USA: SAGE Publishing.

Jo, J.E. and S.H. Park. 2016. Effects of functional mathematics instruction with smartphone calculator application on purchasing skills within budgets of adults with intellectual disabilities. Spec. Educ. Res. [Ewha Womans University] 15(3):5-33. https://doi.org/10.1854 1/ser.2016.08.15.3.5

Joo, B.S., S.A. Park, and K.C. Son. 2012. Improving work 
adjustment skills in students with mental retardation using hydroponics program. Korean J. Hortic. Sci. Technol. 30(5):586-595. https://doi.org/10.7235/hort.2012.12101

Kim, B.G., H.K. Shin, and S.J. Kim. 2019. Effects of the Khan Academy of mathematics learning program on the achievement of mathematics math learning and task performance behaviors of students with intellectual disabilities. J. Spec. Educ. Curric. Instr. 12(4):93-115. https://doi.org/10.24005/seci.2019.12.4.93

Kim, H.D., I.H. Choi, and S.M. Lee. 2014. Effects of horticulture-mathematics integrated education program on math attitude and accomplishment of mathematics in elementary school students. J. Korean Soc. People Plants Environ. 17(3):229-235. https://doi.org/10.11628/ ksppe.2014.17.3.229

Kim, J.J. and H.S. Cho. 2008. Effects of eco-friendly math game construction activity on children's mathematical problem-solving ability and eco-friendly attitude. Early Child. Educ. Res. Rev. 12(6):173-193.

Kim, Y.P. and J.G. Kang. 2015. The effect on computational ability and mathematical disposition of adults with mild developmental disabilities by mathematical board games. J. Rehabil. Res. 19(4):141-157. https://doi.org/10.16884/ JRR.2015.19.4.141

Kim, Y.P., R.K. Kim, and J.G. Kang. 2012. A content comparison of the special education Basic Math A content comparison of the special education basic math with intellectual disabilities in Japan. J. Spec. Educ. Rehabil. Sci. [Daegu University] 51(4):207-227.

Kwack, H.R., S.W. Han, and S.H. Kim. 2009. Effect of integrative environmental program focused on horticultural topics to the environmental attitude and scholarlic achievement of elementary school students. J. Korean Pract. Arts Educ. 20(3):63-78.

Kwack, H.R. and J.K. Kim. 2018. Effect of applicating and developing horticulture-focused STEAM program and manual. J. Korean Pract. Arts Educ. 31(2):41-61. https://doi.org/10.24062/kpae.2018.31.2.41

Lee, B.Y. 2013. The Effects of experiential class using mathematical tools on learning motivation \& academic achievement of math-weak students. Master's thesis, Daegu University, Kyungsan, Korea.

Lee, M.H. and Y.S. Kang. 2014. Effect of functional activity-based mathematics teaching program on money cal- culating ability of students with intellectual disabilities. J. Intellect. Disabil. 16(1):149-175.

Lee, O.I. and E.H. Paik. 2004. The effects of self-instructional strategies using peer-directed and teacher-directed training methods on mathematics for students with mental retardation. Korean J. Spec. Educ. 39(1):213-233.

Lee, S.J. 2012. The development and application of horticultural therapy introduced learning theory of constructivism: Focused on vocational training for adolescents with intellectual disabilities. Doctoral dissertation, Dankook University, Cheonan, Korea.

Lee, Y.J. 2009. Effects of horticulture-mathematics program to thinking ability of elementary school students. Master's thesis, Seoul National University of Education, Seoul, Korea.

Ministry of Education. 2015. Basic curriculum, Supplement 3(Public notice No. 2015-81, pp. 148-185). Sejong, Korea: Author. Retrieved from https://www.moe.go.kr

Ministry of Education. 2018. High school mathematic teacher's guide. Sejong, Korea: Author.

Moon, K.Y. and B.W. Jeon. 2020. Teaching experience of mathematics teachers in the secondary special school for intellectual disability. J. Spec. Educ. Rehebil. [Kongju National University] 24(2):1-32.

National Institute of Horticultural and Herbal Science. 2008. Horticultural integration education program for joyful mathematics: It's all in the garden. Jeonju, Korea: Rural Development Administration.

Park, J.I. 2011. Basic curriculum of special education textbooks and type of vegetation types present analysis. Master's thesis, Wonkwang University, Iksan, Korea.

Park, S.H. 2017. Construction of integrated program for art and science topics of middle school students : view from educational process revision of 2015. Master's thesis, Sungshin Women's University, Seoul, Korea.

Sagong, M.S. 2017. The effects of STEAM-based mathematics teaching on self-efficacy, mathematical attitude and measurement ability of students with intellectual disability. Master's thesis, Korea National University of Education, Cheongju, Korea.

Shin, J.S. 2017. Education for children with intellectual disabilities. Paju, Korea: Yang Seo Won Publishing.

Shin, S.k., H.J. Hwang, J.S. Kim, and S.K. Sung. 1992. 
Mathematical education evaluation system research in pursuit of the true purpose of education( III): Developing evaluation tools for mathematics. Seoul, Korea: Korean Educational Development Institute.

Smith, M.B., J.R. Patton, and S.H. Kim. 2006. Mental retardation: An introduction to intellectual disability(7th ed.). Englewood Cliffs, NJ: Prentice-Hall.

Szymanski, L. and B.H. King. 1999. Practice parameters for the assessment and treatment of children, adolescents, and adults with mental retardation and comorbid mental disorders: American Academy of Child and Adolescent Psychiatry Working Group on quality issues. Am. Acad. Child and Adolesc. Psychiatry 38(12suppl.): 5S-31S. https://doi.org/10.1016/s0890-8567(99)80002-1
White, J.M., K.D. Barrett, J. Kopp, C. Manoux, K. Johnson, and Y. Mccullough. 2006. Math in the garden: Hands-on activities that bring math to life. Burlington, USA: National Gardening Association.

Woo, I.G., B.W. Jeon, C.U. Kang, K.I. Kim, D.H. Kim, J.Y. Kim, O.S. No, M.K. Park, E.H. Park, H.C. Park, H.K. Shin, M.H. Lee, and D.S. Lee. 2015. Review for special education curriculum development in 2015. Chungnam, Korea: National Institute of Special Education.

Yoon, S.L., M.S. Cho, and T.Y. Kim. 2009. Effect of horticultural therapy program using the floral design on the social behavior and grip of intellectual disabled students. J. Korean Soc. People Plants Environ. 12(6):19-30. 